\title{
Implementation of Lean Manufacturing Tools in Footwear Industry of Bangladesh
}

\author{
Md Abu Sayid Mia ${ }^{1,2 *}$, Md Nur-E-Alam ${ }^{3}$, Farid Ahmad ${ }^{2}$ and M. Kamal Uddin ${ }^{2}$ \\ ${ }^{1}$ Institute of Leather Engineering and Technology, University of Dhaka, Bangladesh \\ ${ }^{2}$ Institute of Appropriate Technology, Bangladesh University of Engineering and Technology, Bangladesh \\ ${ }^{3}$ Leather Research Institute, Bangladesh Council of Scientific and Industrial Research, Bangladesh
}

*Corresponding author: Md Abu Sayid Mia, Institute of Leather Engineering and Technology, University of Dhaka, Dhaka-1209, Bangladesh

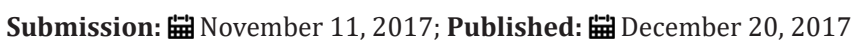

\begin{abstract}
Lean manufacturing is an applied methodology of scientific, objective techniques that cause work tasks in a process to be performed with a minimum of non-value adding activities resulting in greatly reduced wait time, queue time, move time, administrative time, and other delays. This work addresses the implementation of lean principles in a footwear manufacturing industry in order to evaluate present Process Cycle Efficiency (PCE) and lead time prior to developing an improved strategy to bring the improved PCE and to reduce the lead time. At the present state, the PCE was found $15.28 \%$ and after the implementation of lean tools, it would be $34.05 \%$ at the future state where lead time would also be reduced by $55.09 \%$ evaluated by Pareto analysis and value stream mapping tools. The production flow was optimized by minimizing several non-value added activities and time such as bottlenecking, machine breakdown, queue time, waiting time, material handling time, etc. Eventually, this study will be useful in developing a more generic approach to design lean environment in the management system of the studied reputed Footwear Industry in Bangladesh.
\end{abstract}

Keywords: Lean tools; VSM; Lead time; PCE; Technology assessment; Casual shoe

Abbreviations: PCE: Process Cycle Efficiency; D/T: Down Time; C/T: Cycle Time; U/T: Up Time; VD: Value Added Time; NVD: Non-Value Added Time; VSM: Value Stream Mapping; M/C: Machine; RPM: Rotation Per Minute

\section{Introduction}

Finished leather, the main material of footwear, is solely supplied by the local tanneries. Tanneries in Hazaribagh were started in 1960 by Punjabi what was then Pakistan and grew faster and after the independence of Bangladesh in 1971, became a 'cash cow' to earn foreign currencies [1]. Now Bangladesh is set to emerge as the next manufacturing hub for the global footwear industry. It is one of the leading manufacturing industries based on raw material, geographical condition and work force and is highly favourable for the growth of footwear industry [2]. Lean manufacturing is based on the Toyota Production System developed by Toyota which focuses on eliminating waste, reducing inventory, improving throughput, and encouraging employees to bring attention to problems and suggest improvements fix them [3]. Lean manufacturing has increasingly been applied by leading manufacturing companies throughout the world. A core concept of lean manufacturing is pulling production in which the flow on the factory floor is driven by demand from downstream pulling production upstream. Some of the changes required by lean manufacturing can be disruptive if not implemented correctly and some aspects of it are not appropriate for all companies [4]. A lean manufacturing facility is capable of producing the product in only the sum of its value added work content time. On the other hand, applications of lean manufacturing in the continuous process sector have been far fewer [5]. It has sometimes been argued that in part, this is because such industries are inherently more efficient and have a relatively less urgent need for major improvement activities. Managers have also been hesitant to adopt lean manufacturing tools and techniques to the continuous sector because of other characteristics that are typical in this sector. These include large, inflexible machines, long setup times, and the general difficulty in producing in small batches. While some lean manufacturing tools might indeed be difficult to adapt to the continuous sector, this does not mean that the approach is completely inapplicable; for example, [6-12] examine aspects of continuous production that are amenable to lean techniques and present a classification scheme to guide lean implementation in this sector. Features of a typical lean manufacturing model include one unit at a time production; nonvalue added time eliminated production in the work content time only, and relocation of required resources to the point of usage. In the present day of manufacturing, the assembly line can be formed easily for any industry whether it is a small-scale or a largescale industry. When the tact times are calculated for every part manufactured in the industry through different part movements, 
then the problem of locating machines on the shop floor occurs when it is a job type production unit; this problem is the main reason for reconfiguration of machines and layout design for every demand [13]. To eliminate these problems, a proper method is required to achieve a rhythm in manufacturing lean assembly line by identifying value adding, non-value adding, and necessary non-value adding activities through an optimum feasible take time [14]. In the $21^{\text {st }}$ century, footwear industry continues to be a fundamental instrument for sustainable development and poverty reduction where Lean thinking will be able to add a new impressive proportion in the development of footwear industry which could also be considered as the promoter and imperative for meeting the Sustainable Development Goals (SDG) of reducing poverty and hunger by 2030 [15]. This study was masterful with some specific objectives which were to identify, quantify and to reduce the nonvalue added (NVD) activities and time towards the exalted Process Cycle Efficiency (PCE) and therefore to reduce the lead time.

\section{Industrial Implementations of Lean Tools}

With the flow of time and iridescent aptitude of the consumer, today's manufacturing industries are undergoing more and more competition in local and global marketing system to come up with the desired product or service within a limited period of time. Towards reducing the lead time, improving the PCE and ultimately to gain the benefit there is a number of pleasing evidence of successful lean tools implementation in the manufacturing world. Lean tools have been successfully applied in many manufacturing organizations such as general Electric, Boeing, DuPont, Kodak, Honeywell, Texas Instruments, etc. [16]. Lean tools are also successfully applied in hospitals, pharmaceutical, housing and paper industry, and brought with alluring economic benefit by reducing the long lead time and manufacturing waste. It was estimated that over the world by adopting lean tools in pharmaceutical industry a cost could be saved up to $\$ 90$ billion per year [17]. In 1999, it was evaluated that lean tools significantly brought the benefits of $\$ 20$ billion to Motorola Inc. since 1986 that inspired many companies in various industrial sectors to adopt lean tools. In the USA, it was reported that a food manufacturing industry has gained the benefit of $\$ 2$ million per year by adopting lean tools [18]. This riveting economic benefit was the ultimate outcomes of reduced NVD activities, lead time and improved PCE. It was shown a frozen fish industry would able to improve its PCE from $5.02 \%$ to $17.46 \%$ by adopting lean tools [19]. Like these promising studies, the authors were provoked to conduct this study with the lean tools in a Casual shoe production line of the footwear industry, Bangladesh prior to reducing the lead time and to improve the PCE.

\section{Observed Production Line}

In this study, the required ingredients towards the finished Casual shoe were not the concerning matter rather than causes that were responsible for production waste and downtime. The delay in production due to different causes and downtime were quantified in terms of NVD time. The basic stages of Casual shoe production line were as follows in the following Figure 1.

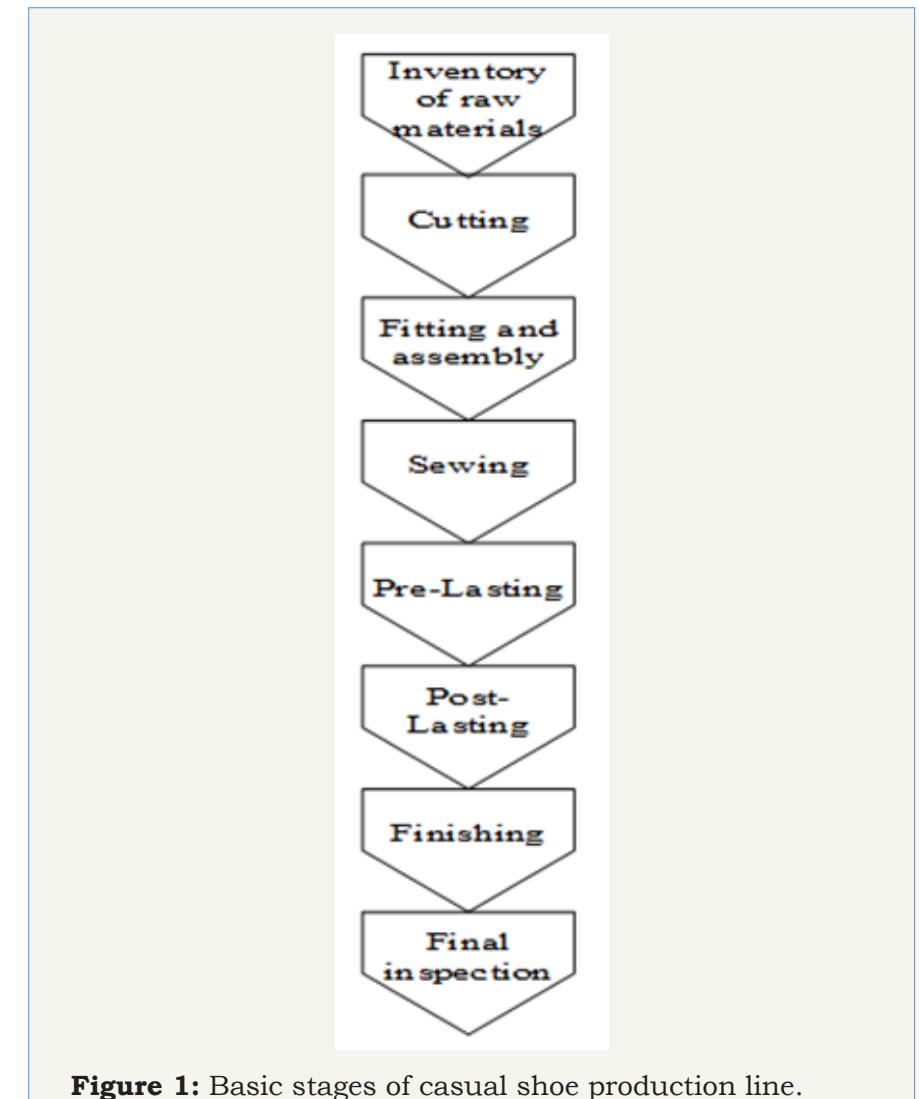

\section{Value stream mapping (VSM)}

A value stream is a collection of all actions (value added as well as non-value-added) that are required to bring a product (or a group of products that use the same resources) through the main flows, starting with raw material and ending with the customer. These actions consider the flow of both information and materials within the overall supply chain. The ultimate goal of VSM is to identify all types of waste in the value stream and to take steps to try and eliminate these [20]. While researchers have developed a number of tools to optimize individual operations within a supply chain, most of these tools fall short in linking and visualizing the nature of the material and information flow throughout the company's entire supply chain. Taking the value stream viewpoint means working on the big picture and not individual processes. VSM creates a common basis for the production process, thus facilitating more thoughtful decisions to improve the value stream [21].

\section{Present value steam mapping (VSM) of casual shoe production line}

To draw the present VSM relevant data in the following Figure 2 like as VD and NVD time, Cycle time, Change Over time, Uptime, Lot size, quantity to deliver, delivery time were observed and information related to assembly line such as production time, inventory storages, inspections, rework loops, number of workers and operational hours per day were collected and documented in [Table $1 \& 2$ ]. To draw the completion of present VSM of Casual shoe production line, a timeline was added at the bottom of the map recording the VD and NVD time. 


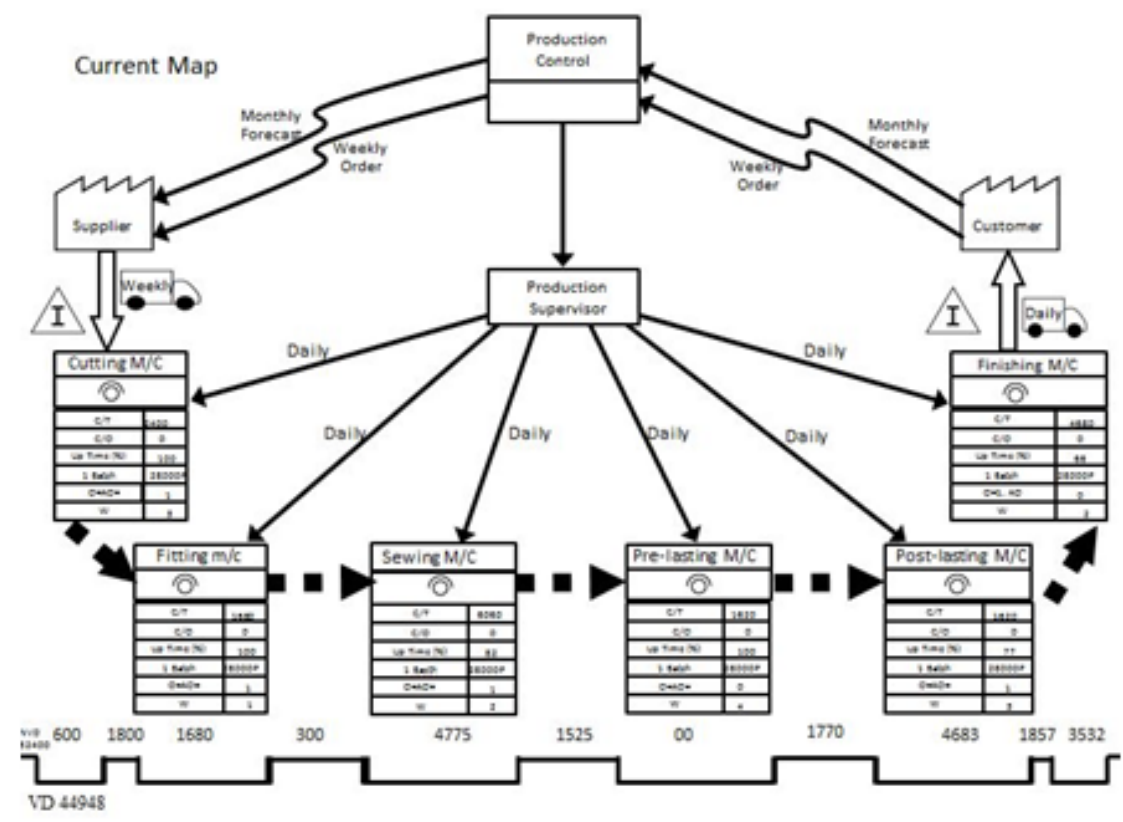

Figure 2: Present value steam mapping (VSM) of casual shoe production line.

Table 1: Manufacturing lead time of casual shoe production line.

\begin{tabular}{|c|c|c|c|c|c|c|c|c|c|}
\hline \multirow{2}{*}{ Times } & \multicolumn{3}{|c|}{ Sewing } & \multicolumn{3}{c|}{ Lasting } & \multicolumn{3}{c|}{ Finishing } \\
\hline & D/T (Sec) & C/T (Sec) & U/T (\%) & D/T (Sec) & C/T (Sec) & U/T (\%) & D/T (Sec) & C/T (Sec) & U/T (\%) \\
\hline $1^{\text {st }}$ & 1116 & 6060 & 81 & 1416 & 6120 & 76 & 1368 & 4680 & 65 \\
\hline $2^{\text {nd }}$ & 1105 & 6060 & 82 & 1415 & 6120 & 77 & 1349 & 4680 & 66 \\
\hline $3^{\text {rd }}$ & 1105 & 6060 & 82 & 1399 & 6120 & 78 & 1341 & 4680 & 66 \\
\hline Average & 1108 & 6069 & 82 & 1410 & 6120 & 77 & 1352 & 4680 & 66 \\
\hline
\end{tabular}

Note: Sewing m/c speed: 276rpm; Lasting m/c speed: 274rpm; Finishing m/c speed: 50 pairs per hour, Batch production-7000 pairs.

Table 2: Present lead time of casual shoe production line.

\begin{tabular}{|c|c|c|}
\hline Processing Stages & Average VD Time (Sec) & Average NVD Time (Sec) \\
\hline Receiving Inventory & 0 & 18400 \\
\hline Cutting & 600 & 300 \\
\hline Fitting \& assembly & 1680 & 1525 \\
\hline Sewing & 4775 & 1770 \\
\hline Pre-Lasting & 0 & 1857 \\
\hline Post-Lasting & 4683 & 1748 \\
\hline Finishing & 3532 & 43200 \\
\hline Shipping inventory & 0 & $84600(84.72 \%)$ \\
\hline Total & $15270(15.28 \%)$ & \\
\hline
\end{tabular}


It helps to draw the required production steps with mentioning required labour, $\mathrm{C} / \mathrm{T}, \mathrm{U} / \mathrm{T}, \mathrm{C} / \mathrm{O}$ and batch size. By observing the present scenario of regarding production line, it can be known like as what number of labour is needed at different production unit? How much is VD \& NVD time present? Where \& what kind of improvement should be done? It helps to calculate the PCE, lead time and tact time.

\section{Present PCE of casual shoe production line}

PCE is measured as the percentage of the ration of VD time and lead time, where lead time is the summation of VD and NVD time. In the observed production line, the VD and NVD time were found as $15270 \mathrm{sec}$ and $84600 \mathrm{sec}$, so the lead time was $99870 \mathrm{sec}$ and consequently, the PCE was $15.28 \%$ which could be considered as the below of internationally comparative level 25\% [19]. Throughout this study, it was strived to improve the present PCE with the proper adoption of lean tools such as VSM, Pareto analysis, Pareto chart, 5S, and JIT.

\section{Present takt time of casual shoe production line}

Takt time is considered as the time that is required to produce a single unit of daily capable quantity of commodities [22]. The studied production line runs for two shifts per day, each shift was for $33600 \mathrm{sec}$ excluding lunch time and planned downtime; therefore, the available time for the run of the studied production line was $67200 \mathrm{sec}$ with the daily customer demand of 5094cases where each case contains 140 pair's Casual shoe. Takt time is

Table 3: Causes of delay times for pare to analysis of casual shoe production line.

\begin{tabular}{|c|c|c|c|}
\hline Causes Of Delay Times & Down Time(D/T) & Percentage Of D/T & Cumulative Of Percentage \\
\hline Inefficient Ironing & 819 & 21.16826 & 38.16826 \\
\hline $\begin{array}{c}\text { Improper Setting During Toe } \\
\text { Lasting }\end{array}$ & 666 & 17.21375 & 52.49418 \\
\hline Needle Thread Breakage & 546 & 14.11217 & 61.97984 \\
\hline Bobbin Thread Breakage & 367 & 9.485655 & 70.04394 \\
\hline $\begin{array}{c}\text { Improper Setting during Seat } \\
\text { Lasting }\end{array}$ & 312 & 8.064099 & 78.08219 \\
\hline Improper Polishing & 311 & 8.038253 & 84.87981 \\
\hline Inappropriate Scouring & 263 & 6.797622 & 89.24787 \\
\hline $\begin{array}{c}\text { Side Lasting Problems Due to } \\
\text { Feather Edge Stitching }\end{array}$ & 169 & 4.368054 & 93.30576 \\
\hline Inefficient Spraying & 157 & 4.057896 & 96.95012 \\
\hline Skipped Stitches & 141 & 3.644353 & 98.63014 \\
\hline Bumps or Hollows & 65 & 1.680021 & 1.369863 \\
\hline Seam Pucker & 53 & & \\
\hline
\end{tabular}

Different causes of NVD activities or downtime at different production stages were documented in Table 3 with their frequency in terms of percentage and cumulative of percentage. Pareto chart is constructed in Figure 3 where the responsible causes for NVD considered as the heartbeat of any process line. By this way, the present takt time of studied production line was 13.19sec i.e. it took 13.19sec to produce a single case of Casual shoe production. By this study, it was tried to reduce the present takt time with the proper implementation of lean tools.

\section{Pareto analysis}

It is a statistical technique in decision making that is used for selection of a limited number of tasks that produce significant overall effect. It uses the Pareto principle - the idea that by doing $20 \%$ of work, $80 \%$ of the advantage of doing the entire job can be generated. Or in terms of quality improvement, a large majority of problems (80\%) are produced by a few key causes (20\%) [23]. The Pareto Principle also is known as the "80/20 Rule" which is the idea that $20 \%$ of causes generate $80 \%$ of results [24-26]. In this study, by using this tool it was tried to find out the $20 \%$ of causes that is generating $80 \% \mathrm{NVD}$ activities. This tool focuses on the most damaging causes on a project. In this essence, David stated that the application of the Pareto chart consisting of causes for downtime or NVD activities along the $\mathrm{X}$ axis while the $\mathrm{Y}$ axis represents the cumulative percentage of downtime. Most of the NVD activities were documented on sewing, pre-lasting, post-lasting and finishing steps where these were frequently observed due to different causes. The highest frequency of NVD activities that derived the downtime was found for toe lasting problems while skipped stitches were the lowest frequency. activities were arranged in downward movements in terms of their frequency. $5 \mathrm{~S}$ and JIT would be effective initiatives to remove these most frequent causes [27]. 


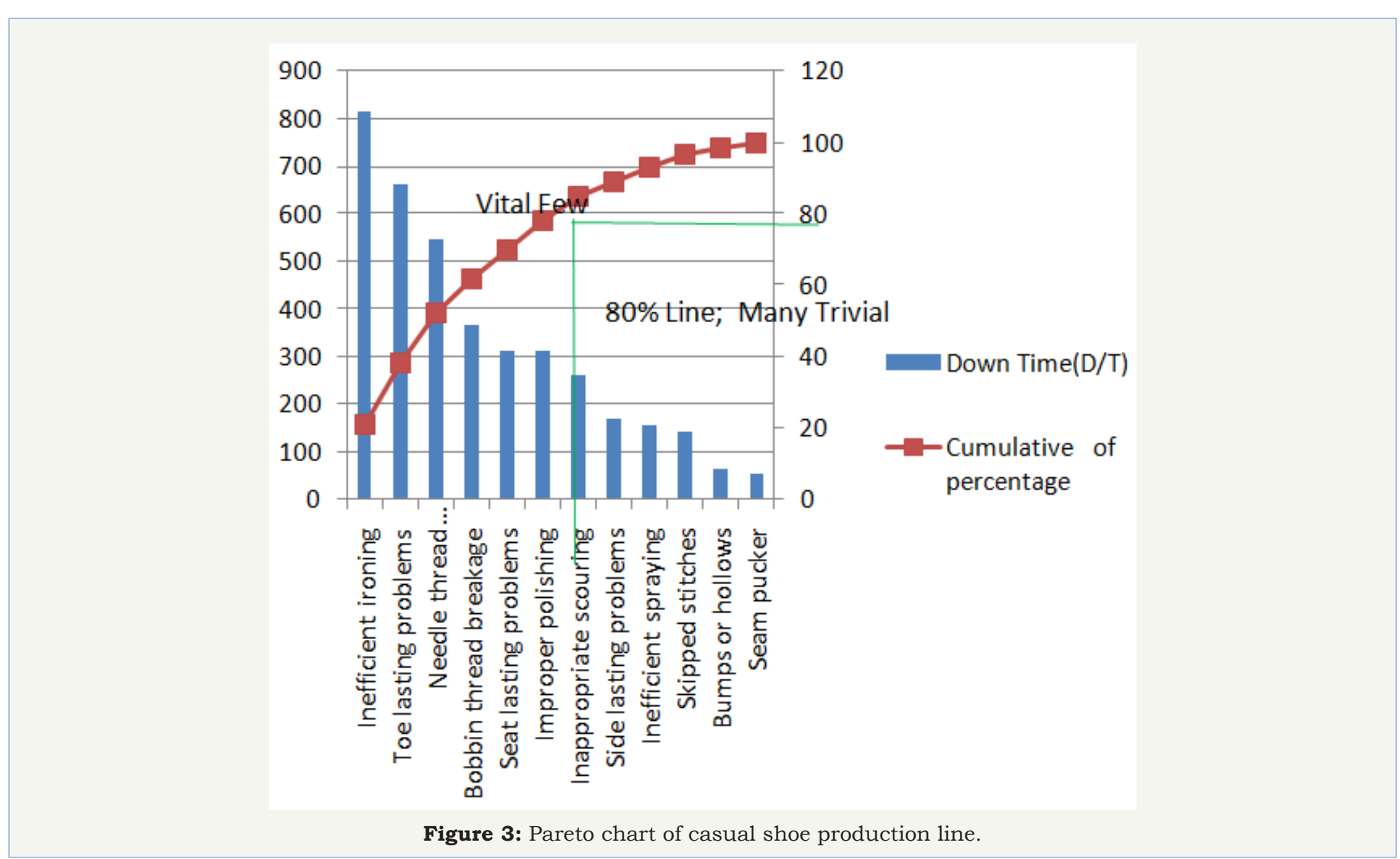

\section{Improvement Strategies}

In order to remove the $80 \%$ NVD activities, indeed it is emergence to take some improvement strategies such as increase skill manpower, continuous improvement, and involvement of JIT philosophy within the production management system.

\section{Increase skill manpower}

It was observed that most of the assistant operators were not enough skilled to handle the machine breakdown immediately. But for this reason, the maintenance time was as high as not acceptable. So, it is suggested to hire some skill manpower as operator and assistant operator especially for sewing, lasting and finishing machine. The effective training program should be arranged prior to make capable of operator and assistant operator towards reducing the maintenance time.

\section{Continuous improvement}

Continuous improvement is one of the most effective and basic tools of lean production which is also known as Kaizen. It is a longterm approach to work systematically to seek and to achieve small, incremental changes in processes in order to improve the efficiency and quality. Kaizen can be applied to any kind of work, but it is well known for being used in lean manufacturing. Kaizen is a Japanese term that reveals the meaning as "good change". Basically Kaizen is considered as a systematic approach for continuous improvement. $5 \mathrm{~S}$ is one of the most popular tools for effective continuous improvement. Towards the NVD activities reduction, $5 S$ is the first modular step. $5 \mathrm{~S}$ is not only a means to increase the profitability of a firm but also allow companies to reveal potential strengths and capabilities that were hidden before [28]. It consists of Japanese words-Seiri (Sort), Seiton (Straighten), Seiso (Sweep and Clean), Seiketsu (Systemize), and Shitsuke (Standardize). The basic and underlying concept of $5 \mathrm{~S}$ is looking for waste and then tries to eliminate it. This concept implies that go there instantly where a problem occurs; checkout the problem; take a temporary measure on spot; find out the main causes beyond the problem, if need uses the five WHY? Question; and finally standardized to prevent reoccurrence [29]. In a production process line, a good change or the improvement can be achieved by many ways such as reduction of inventory, reduction of production time, reduction of defective parts etc. In this essence, a strategic plan is developed prior to implementing the $5 \mathrm{~S}$ in the observed Casual Shoe production line in order to remove the recognized NVD activities. Towards the implementation of 5S, it would be needed a proper plan or vision which could be formulated by the management of foot wear sector. The vision plan should be incorporated with the theme of reducing lead time, NVD activities or manufacturing waste and improving PCE. The plan of 5 Supplemented consisting of team work, training work, multi-skill scope and learning environment. To implement a new plan, teamwork will be an effective wheel to bring the plan into practical. An effective training program should be arranged frequently prior to need for the sake of 5Sincorporation within the existing production management system. An attempt should be constant in order to find out the problem at each and every stage of the Casual Shoe production line. A persistent endeavour should 
be kept on creating a way to eliminate the arising problems and if this way being effective, it must be documented and if not keeping on try towards an effective way beyond the elimination of problems for NVD activities.

\section{Just in time (JIT)}

JIT is a Japanese management philosophy which has been applied in many Japanese manufacturing organizations since the early 1970s. It was first developed by Taiichi Ohno in the Toyota manufacturing plants as a means of meeting consumer demands within the minimum delays [30]. The lean production firstly focuses on what is most commonly thought of as 'just in time' management which is considered as one of the basic principles of lean manufacturing. It is the idea of producing exactly what the customer wants, in the quantities they want, where they want it when the customer wants it without being delayed or held upon inventory [31]. Inman \& Bulfi [32] implied that JIT implementation provokes to reduce hurdles like as long change over time; unlevelled production schedules; highly variable production processes; large container sizes; severe bottlenecks and long lead time.

A system where a customer initiates demand and the demand is then transmitted backward from the final assembly all the way

\section{The Future States of Casual Shoe Production Line}

to raw material, thus "pulling" all requirements just when they are required $[33,34]$. Actually, there are no unified steps towards the JIT implementation; because, the production phenomenon of different factories varies from each other. Moreover, the ability of the different techniques in different factories depends deeply on a specific manufacturing environment. However, benefits from these programs have often been limited because of unreliable or inflexibility [35]. Indeed, it is needed a reliable and flexible environment towards the JIT implementation. In the observed Casual shoe production line unwanted and unnecessary NVD waiting time were observed as very common between each two stages, especially in raw material inventory and finished goods inventory which could be reduced by JIT implementation. In order to JIT implementation, some suggestions were proposed like as-

a. Prepare the plant and its personnel for flexibility towards involving themselves within the JIT principles

b. Regarding personnel should be careful to the shortest lead time and high quality by concentrating maintenance and quality

c. Strive to produce with no waste by focusing on inventory control

\section{Future VSM of casual shoe production line}

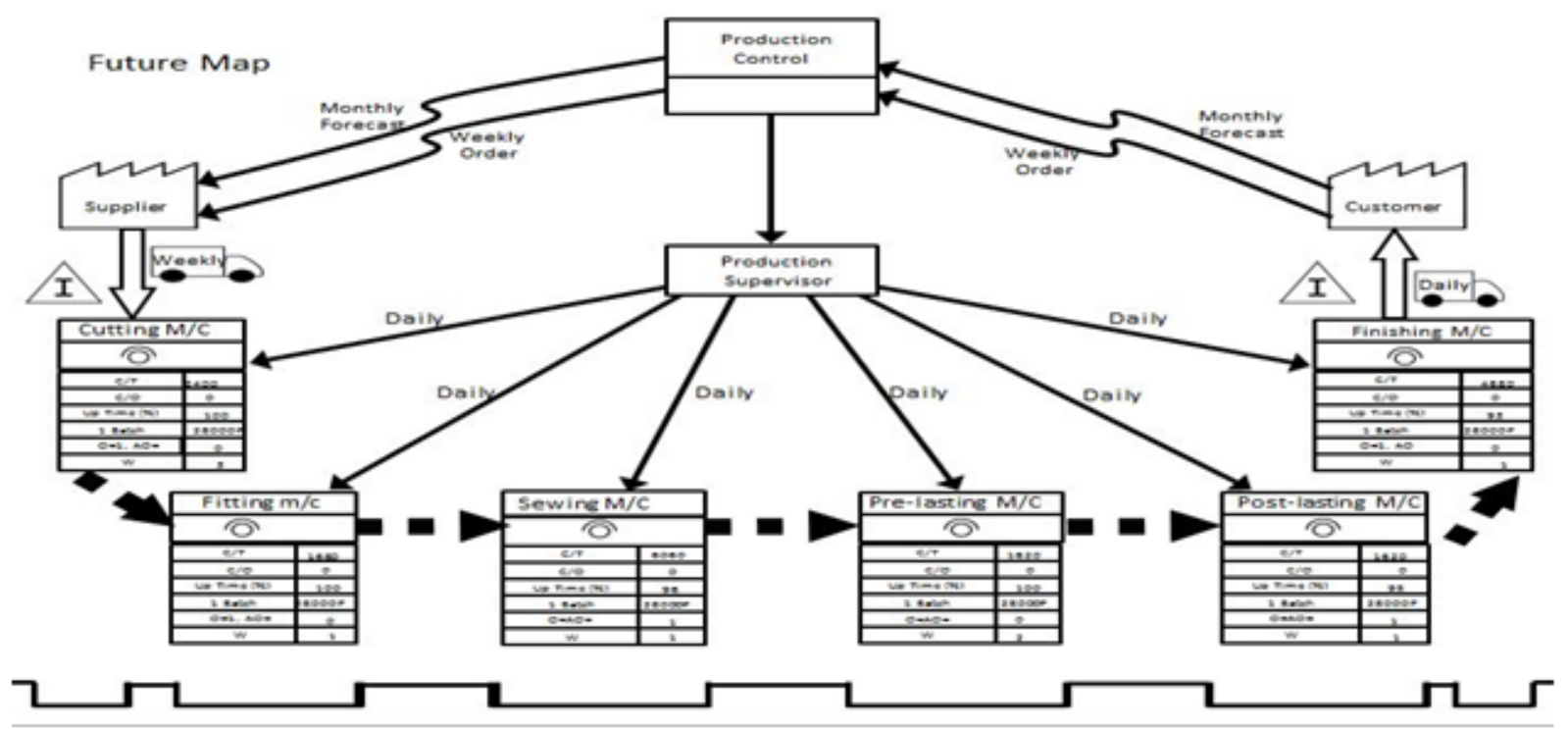

Figure 4: Future VSM of casual shoe production line.

Finally, the future VSM is constructed as shown in Figure 4 which reported a promising reduction in NVD time and lead time with improved PCE and up time. Table 4 outlines the value stream analysis report of casual shoe production line for the future state. It is found that after the implementation of lean tools PCE will be improved at internationally competitive level. Based on intense observation, brainstorming and previous regarding studies it is predicted that $50 \%$ NVD time of raw material inventory and shoe production steps could be reduced. The $80 \%$ NVD time of sewing, pre-lasting, pot-lasting and finishing steps could be reduced after the implementation of lean tools. At future state, the total labour is found 17 , but it was 25 at present state i.e. after the implementation of lean tools at least 07labors could be the relief for another work. Then up time of sewing, lasting and finishing machine is found 
consecutively $96 \%, 95 \%$ and $93 \%$ while it was consecutively $82 \%$, $77 \%$ and $66 \%$ at present state. At future state, it is also found the PCE will be $34.05 \%$ while it was $15.28 \%$ at present state. Therefore, at future state, the promising outcomes bring with the reduction of labour, NVD time and lead time, and improved uptime and PCE.

Table 4: Future lead time of casual shoe production line.

\begin{tabular}{|c|c|c|}
\hline Production Stages & Vd Time (Sec) & Nvd Time (Sec) (Expected Reduction) \\
\hline Receiving Inventory & 0 & $16200(50 \%)$ \\
\hline Cutting & 600 & $300(80 \%)$ \\
\hline Fitting \& Assembly & 1680 & $305(80 \%)$ \\
\hline Sewing & 4775 & $354(80 \%)$ \\
\hline Pre-Lasting & 0 & $371(80 \%)$ \\
\hline Post-Lasting & 4683 & $350(80 \%)$ \\
\hline Finishing & 3532 & $10800(60 \%)$ \\
\hline Shipping Inventory & 0 & $29580(65.95 \%)$ \\
\hline Total & $15270(34.05 \%)$ & \\
\hline
\end{tabular}

\section{Expected PCE at future state}

At future state, it is expected that after the proper implementation of lean tools NVD time from $84600 \mathrm{sec}$ to $29580 \mathrm{sec}$ and thus the lead time would be reduced from 99870 sec to $44850 \mathrm{sec}$. As earlier, it is mention that PCE is measured as the percentage of the ratio of VD time and lead time and consequently at future state, the PCE is found $34.05 \%$ which is considered as the internationally competitive level 25\% [19].

\section{Expected takt time of future state}

In earlier, it is mentioned that takt time is the heartbeat of a production process line. Takt time is the time that needs to produce a single unit of production. As it is lower indicates the faster of production. Throughout this study, it was tried to reduce the takt time. At future state, after the adoption of lean tools, the takt time is found $12.89 \mathrm{sec}$ while at present state production phenomenon it was found $13.19 \mathrm{sec}$.

\section{Achievement of lean tools adoption}

A promising achievement is predicted with the reduced NVD time, lead time and takt time, and improved PCE. An improvement comparison between present and future state is given in the following Figure 5. At future state, it is seen that the NVD time will be reduced $65.03 \%$, lead time will be reduced $55.03 \%$, takt time will be reduced $2.73 \%$ and PCE will be improved $122.84 \%$. But all of these alluring achievements basically depend on the successful implementation of proposed lean tools.

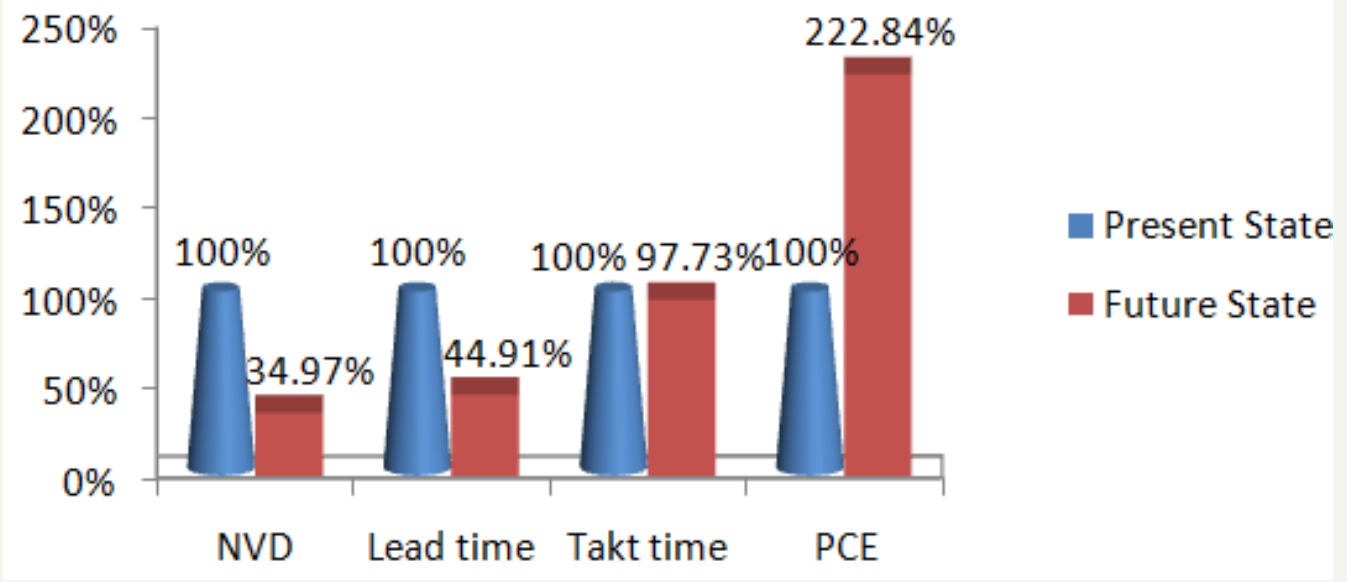

Figure 5: Future VSM of casual shoe production line.

\section{Technology Assessments}

Assessment of technology system components sophistication range and innovation scope of studied footwear industry [36,37] (Figure 6) (Table 5). 


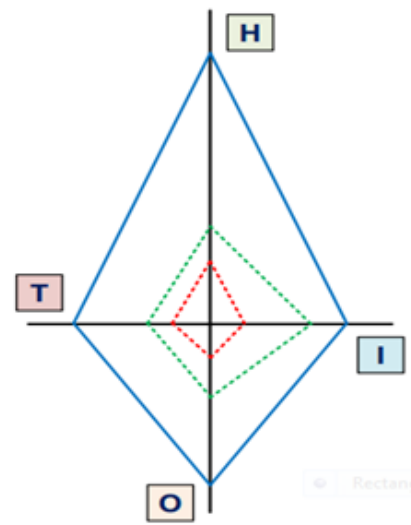

$\begin{array}{ll}\text { Ideal (Best) profile } & \text { : Outer shape(blue) } \\ \text { Current profile } & \text { : Middle shape(green) } \\ \text { Minimum profile } & \text { : Inner shape(red) }\end{array}$

Figure 6: Assessment of technology system components sophistication range and innovation scope of studied footwear industry.

Table 5: Revised the scoring table for assessing degree of sophistication of THIOs using a 9-point overlapping scoring scale with 10 for ideal best.

\begin{tabular}{|c|c|c|c|c|c|}
\hline $\begin{array}{c}\text { Technology } \\
\text { Components }\end{array}$ & $\begin{array}{c}\text { Low Primitive Score: } \\
\mathbf{1 - 2 - 3}\end{array}$ & $\begin{array}{c}\text { Medium traditional } \\
\text { Score: } \mathbf{3 - 4 - 5}\end{array}$ & $\begin{array}{c}\text { High modern Score: } \\
\mathbf{5 - 6 - 7}\end{array}$ & $\begin{array}{c}\text { Top Emerging Score: } \\
\mathbf{7 - 8 - 9}\end{array}$ & Ideal Best Score: 10 \\
\hline Techno ware & Manual & Powered & Automatic & Programmable & Zero Deviation \\
\hline Human ware & Basic & Superior & Advanced & Extra-ordinary & Zero Error \\
\hline Info ware & General & Special & Unique & Frontier & Zero unknown \\
\hline Orga ware & Adhoc & Orderly & Managed & Optimized & Zero tolerance \\
\hline
\end{tabular}

Assessment of product market value using integrated business and technology strategies of Casual shoe [36,37] (Figure 7).

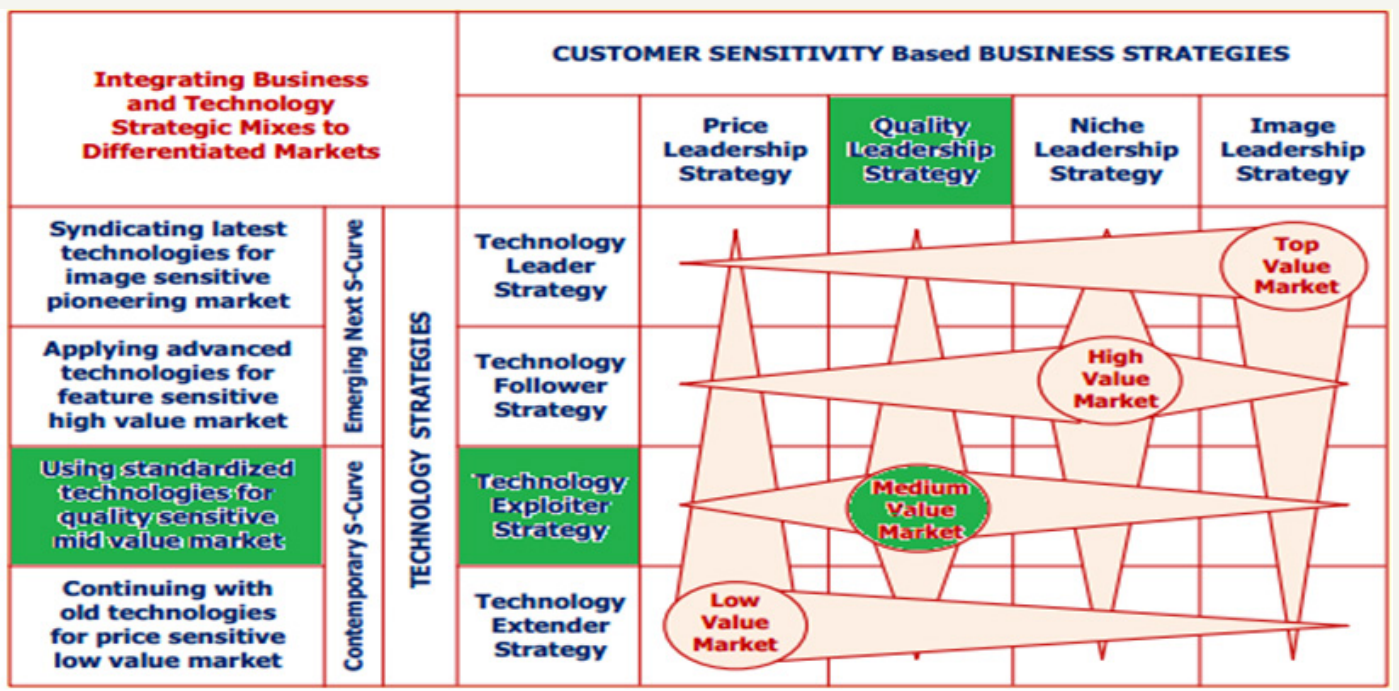

Figure 7: Assessment of product market value using integrated business and technology strategies of Casual shoe.

\section{Conclusion}

This study provides a case analysis of the improvement of a Casual shoe production line by reducing the lead time and improving the PCE by using of lean tools. It focuses the renovation of operations by eliminating the NVD time and lead time and improving the PCE through VSM, Pareto Analysis, 5S, and JIT. In a 
nutshell, it is inferred that a set of lean tool is an effective way to identify and eliminate the manufacturing NVD activities and time.

\section{References}

1. Alam NE, Mia SM, Rahman L, Rahman M (2017) Impacts of tanning process on surface water quality of hazaribagh tanning area dhaka Bangladesh. JECET 6(3): 176-186.

2. Sayid Mia MA, Alam NM, Ahmad F, Uddin KM (2017) Footwear industry in Bangladesh: Implementation of six sigma methodology. Industrial Engineering \& Management 6: 211.

3. Womack JP, Jones DT, Roos D (1991) The machine that changed the world. Harper Collins Publishers, USA.

4. Hobbs DP (2003) Lean manufacturing implementation: A complete execution manual for any size manufacturer. J Ross Publishing USA, $\mathrm{p}$. 264.

5. Abdullah F, Rajgopal J (2003) Lean manufacturing in the process industry. Proceedings of the IIE Research Conference Portland, USA.

6. Ahmad M, Dhar N, Benson R, Burgess B (2005) Model for establishing theoretical targets at the shop floor level in specialty chemicals manufacturing organizations. Robotics and Computer-Integrated Manufacturing 21(4-5): 391-400.

7. Melton T (2005) The benefits of lean manufacturing: What lean thinking has to offer the process industries. Chemical Engineering Research and Design 83(6): 662-673.

8. Radnor Z (2000) Changing to a lean organization: The case of a chemicals company. International Journal of Manufacturing Technology and Management 1(4-5): 444-454.

9. Cook RC, Rogowski RA (1996) Applying JIT principles to continuous process manufacturing supply chains. Production and Inventory Management Journal 12-16.

10. Billesbach JT (1994) Applying lean production principles to a processing facility. Production and Inventory Management Journal 40-44.

11. Abdullah F, Rajgopal J, Needy KL (2002) A taxonomy of the process industry with a view to lean manufacturing. Proceedings of the American Society for Engineering Management Florida 314-321.

12. Abdelmalek F, Rajgopal J, Needy KL (2006) A classification model for the process industry to guide the implementation of lean. Engineering Management Journal 18(2).

13. Kumar RD, Mohanram PV, karthik SG (2011) Process cycle efficiency improvement through lean: A case study. International Journal of Lean Thinking 2(1): 46-58.

14. Womack JP, Daniel TJ (1996) Lean thinking: Banish waste and create wealth in your corporation, USA.

15. Sayid Mia MA, Alam MN, Uddin KM (2017) Footwear industry in Bangladesh: Reduction of lead time by using lean tools. JECET 6(3): 251259.

16. Young HK, Frank TA (2006) Benefits, obstacles, and future of six sigma approach. Technovation 23(5-6): 708-715.
17. Pavlović K, Božanić V (2012) Lean and six sigma concepts. International Journal for Quality Research 6(1): 615.

18. Carlos WM (2006) Optimization of production operations. Optimal lean operations in manufacturing.

19. Zhen Y (2011) Food safety and lean six sigma model. University of Central Missouri, USA.

20. Rother M, Shook J (1999) Learning to see: Value stream mapping to add value and eliminate muda. The Lean Enterprise Institute Inc, USA.

21. McDonald T, Aken EM, Rentes AF (2002) Utilizing simulation to enhance value stream mapping: A manufacturing case application. International Journal of Logistics Research and Applications 5(2): 213-232.

22. Frandsen A, Berghede K, Tommelein ID (2014) Takt-time planning and the last planner. Production Planning and Control Proceedings, Norway.

23. Pareto V (1935) Trattato di sociologia generale firenze engl: The mind and society dover.

24. Kimber RJ, Grenier, Robert W, Heldt JJ (1997) Quality management handbook.

25. Dyche J (2002) The CRM handbook: A business guide to customer relationship management.

26. Arthur LJ (1992) Rapid evolutionary development-requirements, prototyping \& software creation, John Wiley \& Sons, USA.

27. Sayid AM, Alam NE, Murad ABM, Ahmad F, Uddin MK, et al. (2017) Waste management \& quality assessment of footwear manufacturing industry in Bangladesh: An innovative approach. International Journal of Engineering and Management Research 7(4): 402-407.

28. Harry MJ (1998) Six sigma: A breakthrough strategy for profitability. Quality Progress 31(5): 60-64.

29. Tsuchiya K, Soon F (2008) The practice of good housekeeping (5s \& kaizen). Singapore Productivity and Standards Board, Singapore.

30. Womack JP, Jones DT, Ross D (1990) The machine that changed the world. Macmillan Publishing Company, Canada.

31. Monden Y (1998) Toyota production system-an integrated approach to just-in-time. ( $3^{\text {rd }}$ edn), Engineering \& Management Press, Georgia.

32. Inman R, Bulfi RL (1991) Sequencing of JIT mixed-model assembly lines. Management Science 37: 901-904.

33. Feld WM (2000) Lean manufacturing: Tools, techniques, and how to use them, The St. Lucie Press, London.

34. Nahmias S (2001) Production and operations analysis, fourth ed. McGraw-Hill, USA.

35. Tajiri M, Gotoh F (1992) TPM implementation: A Japanese approach McGrawHill Inc., USA.

36. Mia AS, Alam NE, Uddin MK Court shoe production line: Improvement of process cycle efficiency by using lean tools. Leather and Footwear Journal Balkans, Romania.

37. Sharif NM (2012) Fundamentals of technological innovation for global competition. Book of knowledge viewgraphs. 